\title{
ENGLISH TEACHERS' USE OF TARGET LANGUAGE: A STUDY IN SONG CONG PRIMARY SCHOOLS
}

\author{
Nguyen Thi Hong Minh*, Nguyen Thi Thu Huong, Nguyen Thi Ngoc Lan \\ TNU University of Education
}

\section{ABSTRACT}

In the field of foreign language teaching, it has widely been believed that using target language extensively has positive influences on the effectiveness of the teaching and learning. Nevertheless, in some certain cases where the teachers demonstrate low proficiency, lack of confidence and do not use English as routines, the teacher's use of the target language has not become a regular practice and the quality of this such use is still in dispute. This article has examined the current situation of teachers' use of target language in Binh Son 1, Binh Son 2 and Cai Dan primary schools in Song Cong City, Thai Nguyen Province, Vietnam. Moreover, the paper has pointed out the teachers' difficulties in maximizing the target language use. Questionnaire and observation are used to collect data to explore the answers to research questions. Five teachers at Cai Dan, Binh Son I and Binh Son II primary school are involved as participants in the study. Based on the recommendations by American Council on the Teaching of Foreign Languages (ACTFL), the research has further discussed specific strategies on enhancing the use of English instructions in Vietnamese context.

Key words: target language use, nativel first language, English instructions, classroom language; English primary school teachers; Song Cong City

Received: 03/5/2019; Revised: 31/5/2019; Approved: 31 /5/2019

\section{NGHIÊN CƯUU VIỆC SỬ DỤNG NGÔN NGŨ ĐÍCH TRONG LỚP HỌC CỦA GIÁO VIÊN TIẾNG ANH CẤP TIỂU HỌC Ở THÀNH PHỐ SÔNG CôNG}

\author{
Nguyễn Thị Hồng Minh", Nguyễn Thị Thu Hương, Nguyễn Thị Ngọc Lan \\ Trưòng Đại học Su phạm - ĐH Thái Nguyên
}

\section{TÓM TĂT}

Trong lĩnh vực giảng dạy ngoại ngữ, rất nhiều nghiên cứu đã và đang khẳng định những ảnh hưởng tích cực của việc sử dụng ngôn ngữ đích trong lớp học đối với hiệu quả của dạy và học ngoại ngữ. Tuy nhiên, trong một số trường hợp, khi giáo viên có năng lực ngoại ngữ không cao, không tự tin và không thực hành thường xuyên, việc sử dụng tiếng Anh để giảng dạy tiếng Anh chưa phải là một thực hành thường xuyên và chất lượng của việc sử dụng ngôn ngữ đích cũng còn rất nhiều vấn đề đáng bàn. Bài báo này nghiên cứu thực trạng sử dụng tiểng Anh trong lớp học của giáo viên tiếng Anh ở trường Tiểu học Bình Sơn 1, Bình Sơn 2 và Cải Đan, thành phố Sông Công, tỉnh Thái Nguyên, Việt Nam. Đồng thời, bài báo cũng chỉ ra những khó khăn khiến người giáo viên không thể tối đa hóa thời gian sử dụng ngôn ngữ đích trong lớp học. Nghiên cứu sử dụng 2 công cụ thu thập dữ liệu chính là bảng hỏi và quan sát nhằm tìm ra câu trả lời cho câu hỏi nghiên cứu. Khách thể nghiên cứu trong bài báo này là giáo viên tiếng Anh ở 3 trường tiểu học ở thành phố Sông Công. Dựa trên những khuyến nghị của Hội đồng Giảng dạy Ngoại ngữ Hoa Kỳ (ACTFL), chúng tôi thảo luận những các chiến lược cụ thể nhằm tăng cường việc sử dụng tiếng Anh của giáo viên trong lớp học ngoại ngữ trong bối cảnh Việt Nam.

Từ khóa: sủ dụng ngôn ngũ đich, giảng dạ bằng tiếng Anh; ngôn ngũ lớp học; giáo viên tiếng Anh cấp tiểu học; thành phố Sông Công

Ngày nhận bài: 03/5/2019; Ngày hoàn thiện: 31/5/2019; Ngày duyệt đăng: 31 /5/2019

* Corresponding author. Email: hminh8782@dhsptn.edu.vn

DOI: https://doi.org/10.34238/tnu-jst.2019.06.1061 


\section{Introduction}

For years there have been long debates on the influence of the mother language on foreign language learning. Different authors have recurrently confirmed the positive impact of the native language on second language teaching and learning. The first language (L1) can assist the study of the second language [1]; the sound knowledge of the native language supports the transfer of skills from one language to another [2]. Therefore, the use of the mother language in foreign language classrooms has recently been encouraged for it reduces learners' anxiety [3] and it provides a more relaxing and comfortable environment [4]. Furthermore, Atkinson (1987) [5] and Buckmaster (2000) [6] share the same viewpoint that L1 usage facilitates the teacher's checking understanding and giving instructions as well as explaining the meaning abstract words.

On the other hand, a large body of research has reached a consensus that the language learner needs to be exposed to the target language extensively [7], [8] since learners who have more exposure to the target language (TL) input demonstrate greater proficiency [9] and TL use will result in increased motivation thanks to the students' awareness of the immediate usefulness of TL [10]. In addition, Liu (2008) [11] Turnbull (2001) [12] and have indicated that the amount of TL input does affect learners' target language development. Consequently, countries all over the world have issued guidelines for the proportion of TL with most agreements on the maximization of TL use in class. More specifically, American Council on the Teaching of Foreign Languages (2010) suggests that the ideal amount of time for target language use in foreign language classes should be $90 \%$ plus at all levels of instruction during instructional time and, when feasible, beyond the classroom [13].

In countries where English is taught as a foreign language in schools, students' only opportunity to practice the language is in the classroom and thus the use of the TL seems restricted to the classroom environment. In those contexts, Mollers (2013) emphasizes the significance of teacher use of TL and similarly, Orland-Barak and Yinon (2005) highlight the instructors' key role in increasing opportunities for TL exposure [14]. The reason for this is TL serves as the only source of scaffolded input and according to Macaro (2001), the entire teaching through the TL makes the language real and "allows learners to experience unpredictability and develops the learners' own in-built language system" [15]. This is particularly true for young students since, as Pinter (2006) believes, it supports their familiarization with the phonological system of the TL [16]. Therefore, it is widely accepted that the competencies of English teachers should include language use competence [17] and classroom English proficiency, in Le's (2017) words, is "no less important than general English language proficiency" [18].

Nevertheless, many English primary teachers in Vietnam (whose general English language proficiency is required lower and in fact in many circumstances demonstrates weaker) are reluctant to practice frequent extensive use of the TL in the classroom. This article investigates the situation in a specific local area of Song Cong City, Thai Nguyen Province, Vietnam and attempts to explore the difficulties facing the primary teachers in Song Cong City in extensively using English in classroom as well as presents some recommendations to maximize the use of TL.

\section{Method}

Qualitative research method is applied in the study with the employment of a combination of questionnaire and observation as data collection instruments which seek to answer the three research questions: (i) what is the reality of teachers' use of target language in Cai Dan Primary School, Binh Son 1 Primary School and Binh Son 2 Primary School; (ii) what difficulties they have encountered in 
using the target language in class; and (iii) what are the suggestions for improving the quality of using the target language for the teachers at Song Cong primary schools. Five (5) female teachers of English at three primary schools in Song Cong City are invited as the research participants. Questionnaires are delivered to the five teachers to have an understanding of the current situation of using English instructions and their difficulties in using TL in English classes. Additionally, one lesson for each teacher is observed to gain a deeper insight of the situation, especially of the quality of teachers' TL use.

\section{Findings and Discussion}

\subsection{The reality of the teachers' use of $T L$}

Figure 1 demonstrates the frequency and the amount of time of the teachers' use of TL in an English class. From the result collected from questionnaires, it is shown that $60 \%$ teachers often used English classroom language in their lessons and 40\% sometimes used it; there were no teachers rarely or never deploying classroom language. The Figure also illustrates $60 \%$ of the teachers spent from 25 to 35 minutes using English classroom language, which is nearly full of a lesson of 35 minutes while the others only spent from 15 to 25 minutes, accounting for $60 \%$ of a period.

According to the results from observation checklists as described in Figure 2, 60\% of the teachers used classroom language from 15-25 minutes, which is similar to the results from questionnaires. Besides, the same percentage of $20 \%$ of the teachers used classroom language from 25-35 minutes and 0-15 minutes using it, which is amazingly quite different from the results from questionnaires. Obviously, the amount of time for English classroom language in a period from questionnaire is quite different from the actual class time devoted to TL. Hence, to some extent it can be said that information withdrawn from questionnaires does not reflect the current reality of using classroom language: The data indicates that the teachers do not use classroom language all the time as they self-reported in the questionnaires.

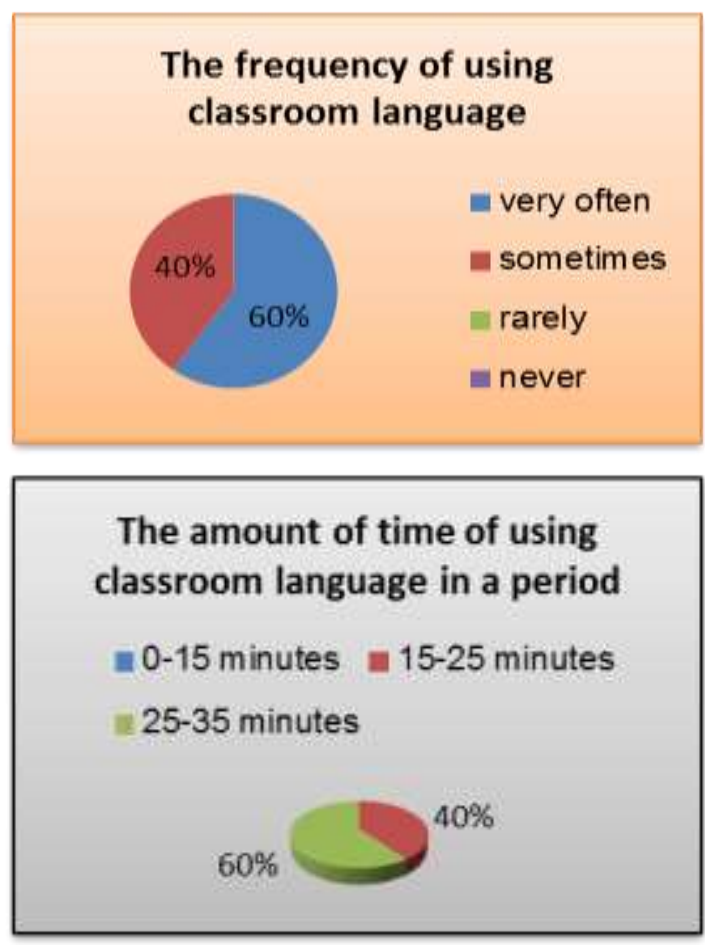

Figure 1. The frequency and the amount of time of using $T L$

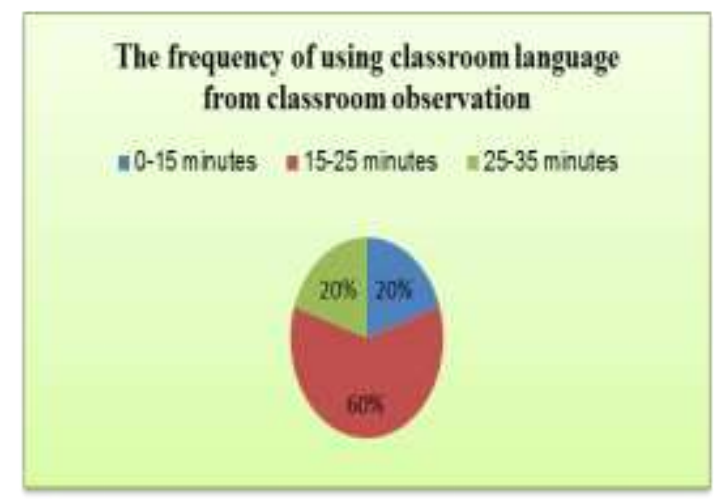

Figure 2. The amount of time of using TL from classroom observation

The results from observation checklists demonstrate that all the teachers used TL for greeting, making questions and giving feedback for their lessons. There were some certain structures and phrases which the teachers used during their lessons, as presented in Table 1. However, not many 
teachers used classroom language for giving instructions; only $20 \%$ of them totally used English classroom language to give instructions while the majority of them gave instructions in English and then explained in Vietnamese. In addition, $80 \%$ teachers did not use classroom language when they wanted to explain the requirements of the task or summarize the lesson, which means only $20 \%$ of them used TL for those activities. None of the teachers used classroom language for making transition to the following part in the lessons, which proves that this activity has not been popular in English lessons at Cai Dan, Binh Son 1 and Binh Son 2 primary schools.

Table 1. TL use in activities

\begin{tabular}{|c|c|c|}
\hline Activities with TL use & $\begin{array}{c}\text { Percentage } \\
(\%)\end{array}$ & Structures or phrases that the teachers used \\
\hline Greeting & $100 \%$ & "Good morning", "Hello everyone" \\
\hline Making questions & $100 \%$ & $\begin{array}{l}\text { "How many people are there in this picture?", "Do you have } \\
\text { a doll?", "How many pictures are there?", "What's the } \\
\text { weather like?", "Are you ready?", etc. }\end{array}$ \\
\hline Giving feedback & $100 \%$ & "Good", Thank you. Sit down, please", "OK", "Well done". \\
\hline Giving instruction & $20 \%$ & $\begin{array}{l}\text { "I give you three times to listen. The first time you listen. } \\
\text { The second time you listen and number. The third time you } \\
\text { check it." }\end{array}$ \\
\hline Giving explanation & $20 \%$ & $\begin{array}{l}\text { "I have a game called "Slap on the board". When I say } \\
\text { "cloudy", you slap on the word "cloudy". When I say } \\
\text { "cloudy", you slap on the word "sunny" so you're wrong." }\end{array}$ \\
\hline Summarizing the lesson & $20 \%$ & "Today we stop here. Thank you". \\
\hline $\begin{array}{l}\text { Making transition to the } \\
\text { next part }\end{array}$ & $0 \%$ & \\
\hline
\end{tabular}

\subsection{The quality of English primary teachers' $T L$ use}

The charts shown in Figure 3 present the rate of fluency and accuracy in some language aspects which is taken from observation checklists.
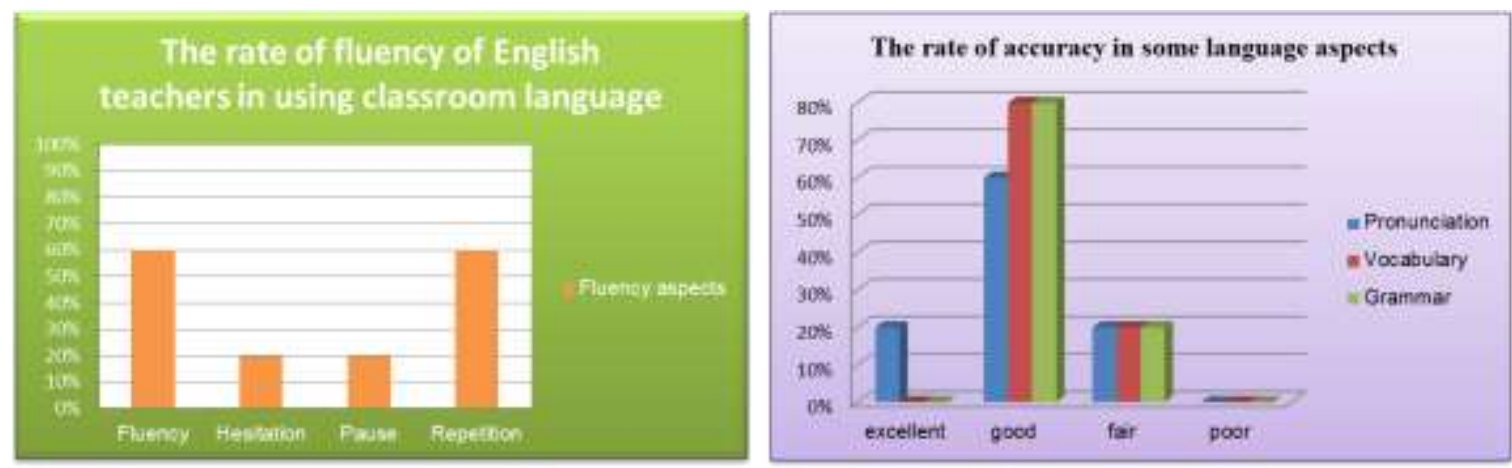

Figure 3. The rate of fluency and accuracy of English teachers' TL use

Figure 3 depicts the rate of fluency in using classroom language. As displayed in the Figure, the rate of fluency is $60 \%$, proving that quite a big number of the teacher are fluent to use classroom language; however, the rate of repetition is also $60 \%$, which means the teachers repeated the structures as well as vocabularies many times. Moreover, a small number of teachers still hesitated and paused while they were using TL; this may make their lesson not go smooth in its process. 
It is clear from the Figure that some of the teachers were quite good at language aspects (pronunciation, vocabulary and grammar). Nonetheless, only one teacher was excellent at pronunciation, while some of them were good $(60 \%)$ and one of them was fair $(20 \%)$. Although no one was bad at pronunciation, there were some teachers whose pronunciation was below B2 level requirements; for example, they made mistakes in pronunciation such as "s" sounds or consonants $/ \mathrm{l} /$ and $/ \mathrm{n} /$. Besides, teachers sometimes used L1 to explain or give instructions to students, or they spoke English and then explained in Vietnamese. In addition, some teachers are not good at some language aspects such as fluency, pronunciation, vocabulary and grammar, which does not reflect English proficiency at B2 level as required.

\subsection{The teachers' difficulties in using $T L$}

Table 2 presents the problems in using TL that the teachers have been encountering. It can be seen that all the teachers have problems in giving instructions which students cannot understand. $100 \%$ of the teachers admitted that they could not use TL in all class time. The source of this problem came from the fact that most students lived in the rural areas, so they had few chances to improve their English skills and have difficulty understanding English, which prevents the teachers from full use of English instructions. A further difficulty is timelimited (appromiximately 60\%), which means that the teachers are afraid that they do not have enough time, so they use Vietnamese instead to explain to students. Besides, large classes (40\%) and mixed ability (40\%) in classes are also the reasons why classroom language cannot be used very often. Another factor that affects the quality of using classroom language is the fact that students do not support them, so they cannot do the task successfully.

These difficulties reported by the English primary school teachers in Song Cong City are congruent with Tennant and Negash's (2009) [19] list of possible problems in TL use. All teachers agree that students cannot understand what they say is the difficulty in the first place driving the teachers not to use TL extensively. Nonetheless, it is revealed from the observation that $60 \%$ of the students can totally understand the teachers' instructions and can perform the given tasks successfully. Therefore, this should not be accounted as the teacher's difficulties in maximizing the TL use in English classes.

Table 2. Teachers' difficulties in using $T L$

\begin{tabular}{llc}
\hline & Problems in using TL & Percentage \\
\hline 1 & Students cannot understand what you say & $100 \%$ \\
2 & You worry that you do not have the time and that it is faster to explain to students in L1 & $60 \%$ \\
3 & Large classes (difficult to speak English as not all students understand) & $40 \%$ \\
4 & Mixed ability classes & $40 \%$ \\
5 & Students do not support you, so they do the task unsuccessfully & $20 \%$ \\
6 & You are not used to using English classroom language & $0 \%$ \\
7 & You are not confident enough to use English in the class & $0 \%$ \\
8 & You do not actually know the right words or phrases & $0 \%$ \\
\hline
\end{tabular}

Moreover, though no teachers have reported "You are not used to using English classroom language", "You are not confident enough to use English in the class" and "You do not actually know the right words or phrases" as their problems, due to the low rate of fluency and accuracy (as discussed above), it can be withdrawn that the English primary teachers in Song Cong City are not very proficient in TL use and the practice of using English instructions have not been a 
regular practice of the teachers. Furthermore, the factors preventing the teachers from using the TL in class extensively should not exclude the problems from the instructors themselves. This, in consequences, may suggest more effective professional development courses in which enhancing the use of English classroom language is supposed to be a crucial component.

\section{Conclusion and Recommendations}

The article has examined the situation of TL use in English classes in Song Cong primary schools. The results indicate that the amount of time devoted to TL use in those schools does not reach the amount of $90 \%$ plus as recommended by ACTFL (2010) [13]. Moreover, the quality of teacher's TL use is still in question with the low rate of fluency and accuracy.

As suggested by ACTFL (2010), in order to maximize TL use, teachers should consider applying a variety of strategies including: providing a language-rich environment; Supporting comprehension and production through context/gestures/visual support; Focusing on meaning before details; Conducting comprehension checks to ensure understanding; Negotiating meaning with students and encourage negotiation among students; Eliciting talk that increases in fluency, accuracy, and complexity over time; Encouraging self-expression and spontaneous use of language; Teaching students strategies for requesting clarification and assistance when faced with comprehension difficulties; Avoiding the mother tongue as the default for checking on meaning or understanding [13].

\subsection{Providing a language-rich environment}

It is discussed in the earlier parts that it is the teacher's key role to offer students with a rich language environment which includes everything that the learners encounter. Sometimes with simple feedback like "Good job", You're gorgeous", "You got it", Better try next time" can provide natural language use as well as encourage students to fulfill language tasks. Moreover, when students are surrounded by authentic inputs supplied and prepared by the instructors, it is more likely that they will increase the intake to transform what they have exposed in English class into their own repetoire.

\subsection{Supporting comprehension and production through context/ gestures/ visual support}

Learners at all levels seem to acquire TL more effectively if the teachers' instructions in TL are supported through context, gestures, visual objects, or connections with prior learning or experiences. It is particularly true with students at primary schools who prefer animation and are more engaged with visual things regardless of whether they are visual learners or not. The biggest benefit this strategy can offer is keeping and increasing students' interest and motivation in learning. The feeling of comfort in a friendly language environment to a large extent can guarantee students' comprehension in and production of the TL.

\subsection{Focusing on meaning before details}

Before digging in to figure out details or nuances, primary students need support to get a general understanding of what is heard, read, or viewed, which will facilitate their success in classroom task performance. It is the instructors that provide students with a strong context, visuals, and a focused task such as finding out what is new information, or figuring out the main idea. Once students' understanding of meaning is formed, they will feel more comfortable and motivated in learning; the effectiveness of English learning is better guarantted and thus the teacher's use of TL will bring about benefits for both teachers and learners.

\subsection{Conducting comprehension check to ensure understanding}

Students take many advantages from showing their understanding frequently. Frequent comprehension checks give students feelings that their efforts are valued and know what is necessary for them to improve upon. These comprehension checks also give teachers essential data to adjust their English instructions, whether they need to change 
their instruction-giving techniques or develop better TL use to support students' understanding.

\subsection{Negotiating meaning with students and encouraging negotiations among students}

Learning takes place when learners are engaged and become essential part of the process. Teachers should help this happen by encouraging students' participation in class negotiation. During an interpersonal activity to negotiate meaning and ideas, learners may need certain phrases to make their interactions more natural and teachers can provide these in the moment, adding key phrases to a physical or virtual "word wall" for learners to access during future language activities.

\subsection{Eliciting talk that increases in fluency, accuracy, and complexity over time}

In order to raise primary students' speaking skill, teachers should make simple questions such as tag questions or yes/no questions. The teachers also need to encourage students to interact with them by adding more details (who, when, what, etc.) since learners practice asking such questions, their speaking performance with increasing rate of fluency, accuracy and complexity will be improved over time.

\subsection{Encouraging self-expression and spontaneous use of language}

It is crucial for students to realize from the beginning that they can respond in the TL, though simply at the word-level or with comprehensive gestures. This can be supported by teachers' giving lots of choices using visuals and repetitive phrases that can be easily modified. As confidence builds, young learners should be encouraged to mix and match their language chunks to create their own messages. Students who apply their learned vocabulary and/or structures in new contexts are making their progress in English learning.
4.8. Teaching students strategies for requesting clarification and assistance when faced with comprehension difficulties

To maintain target language use by both teachers and learners in English classes in primary schools, set phrases should be taught for students to ask for help or clarification in the target language (What? Huh? What do you mean by __ ? How do you say __? I don't understand. Can you repeat that?). These learning aids, as well as other common classroom phrases, can be included on a "word wall" or printed on a list that can be given to the learners or even taped to desks.

\subsection{Avoiding the mother tongue as the default for checking on meaning or understanding}

Another importance strategy is making careful instructional decisions about when NOT to use TL (keeping the minimum amount of classtime of what students say, hear, read, write, or view in the mother language). Teachers should maintain that for deeper processing of understanding in generally private exchanges between teacher and student, for reflection on the learning process or for explaining deeper understanding on an assessment. Native language use of Vietnamese is reserved for some certain situation and purposes, such as explaining why this approach is worthwhile and what learners should expect in this class (not knowing every word, but being able to guess at the meaning and show understanding in a variety of ways), to briefly explain a concept that would take too long to act out or demonstrate, or to allow for brief processing of an idea. The mother tongue should not be an easy default choice - otherwise, learners simply wait to hear words given in Vietnamese. This does not help build up students' English yet decrease their efforts and strategies in communicating in the TL.

From the revealed findings, it is seen that the teachers have been encountering some difficulties in using TL. The following recommendations are based on those difficulties. 


\subsection{Combine the use of $C L$ with communication strategies}

All of the teachers admit that their students do not understand. Therefore, they should use more communication strategies such as body language, gestures, voice, or eye contact to provide more support for the students. Such communication strategies help students find it easier to understand the teachers' instructions, be able to follow the instructions and perform given tasks successfully.

\subsection{Improve their use of TL competence}

Not only should the teachers improve their general English competence, but they also develop their TL competence. They should attend workshops organized by Thai Nguyen DoET where they are not only equipped with current trends in English teaching methodologies but also can exchange their experience with other fellow teachers in the field.

\subsection{Set an ideal English class that is suitable for primary students}

According to the MoET, there are no more than 35 students per classroom; however, many primary schools in Vietnam have been overloaded with students, which reduces the quality of teaching and learning. Therefore, the ideal English class should have such desired size to ensure that every student can practice and interact with the teachers and other students.

In conclusion, improving teachers' use of TL is very important. Using TL everyday develop teachers' general English competence as well as TL competence and help their students get used to using English extensively in the class. It is obvious that teachers' use of TL as authentic inputs for students facilitates the achievement of the ultimate goal in EFL learning.

\section{REFERENCES}

[1]. Cook, V., Using the First Language in the Classroom, Canadian Modern Language Review, 2001.
[2]. Clarke, P., Supporting Children Learning English as a Second Language in the Early Years (birth to six years), Victorian Curriculum and Assessment Authority, 2009.

[3]. Auerbach, E., Reexamining English only in the ESL classroom, TESOL Quarterly, 1993.

[4]. Burden., The Use of the Students' Mother Tongue in Monolingual English "Conversation" Classes at Japanese Universities, TLT Online Editor, 2000.

[5]. Atkinson., Teaching monolingual classes, London: Longman, 1993.

[6]. Buckmaster, R., First and second languages do battle for the classroom, The Guardian, 2000.

[7]. Ellis, R., The Study of Second Language Acquisition, Oxford University, 2008.

[8]. Krashen, Second language Acquisition and Second Language Learning, Pergamon Press, 1981.

[9]. Larsen-Freeman, Input in second language acquisition, 1985.

[10]. MacDonad, Using the target language. Cheltenam: Mary Glasgow Publications, 1993.

[11]. Liu, J., L1 Use in L2 Vocabulary Learning. Facilitator or Barrier. International Education Studies, 2008.

[12]. Turnbull, There is a role for the L1 in second and foreign language teaching. Cadanian Morden Language Review, 2001.

[13]. ACTFL, Use of the target language in the classroom, 2010.

[14]. Orland-Barak \& Yinon, Different but similar: Student teachers' perspectives on the use of LI in Arab and Jewish EFL classroom settings, Language, Culture and Curriculum, 2005.

[15]. Macaro, E., Analyzing Student Teachers' Codeswitching in Foreign Language classroom: Theories and Decision Making. The Modern Language Journal, 2001.

[16]. Pinter, Teaching young language learners. Oxford: Oxford university Press, 2006.

[17]. Richards, J. C., Competence and performance in language teaching. RELC Journal, 2010.

[18]. Le, Van Canh \& Willy Renandya, Teacher's English Proficiency and Classroom language Use. RELC Journal.

[19]. Tennant, A. and Nigussie Negash, Language Improvement for English teachers. British Council, 2009. 